\title{
Allometric relations for Ceriodaphnia spp. and Daphnia spp.
}

\author{
J.L. Pereira, C.R. Marques, F. Gonçalves
}

Departamento de Biologia, Universidade de Aveiro, Campus Universitário de Santiago, 3810-193 Aveiro, Portugal. E-mail: jpereira@bio.ua.pt

\begin{abstract}
Ecotoxicological studies with cladocerans frequently assess the individual growth of the organisms. Measures upon living organisms should be avoided once they can lead to their death or affectation, therefore constraining the results. In this way, and considering that cladocerans species go through series of moults along their life cycle, measures upon the moult are preferred in almost all the studies. Thus, the establishment of allometric relations is required to enable feasible estimations of diverse growth parameters. Exopodite and total body length of two autochthonous (Daphnia longispina; Ceriodaphnia pulchella) and two standard (Daphnia magna; Ceriodaphnia dubia) living daphnids were registered. Regression analysis was applied in order to establish a relation between the two allometric measurements in each species. As high R-squared values were reached in all species, the obtained equations can be used as reference for estimations of body length in face of the «moult» exopodite length measure. Consequently, this work provides a support reference for ecotoxicological studies performed in lab with these species.
\end{abstract}

Keywords : allometric estimations, body length, Ceriodaphnia dubia, Ceriodaphnia pulchella, Daphnia magna, Daphnia longispina, exopodite length, individual growth.

\section{Introduction}

Cladocerans and specifically daphnids play an important role on limnetic environments, being the dominant consumers of primary producers, but also an important food supply for both invertebrate and vertebrate predators (Baudo 1987). In addition, even recognising the doubts expressed by some authors about the representativeness of the daphnids and about the ecological relevance of laboratory tests, they also still rallying singular characteristics which make them successful test organisms (Forbes 1999, Barata et al. 2000).

In this way, cladocerans, and specially daphnids, have been extensively used as a representative group of freshwater invertebrates in ecological and toxicological studies. There are a certain number of life-history traits which are commonly assessed on ecotoxicological assays carried out with these animals. Some of them, for example, evolve measurements to estimate growth rates. As referred by Soares (1989) measurements on living organisms should be avoided, as on pain of death can occur loose or affectation of the ani- mals. The same author reminds that daphnids go to series of moults and growth only occurs immediately after moulting, when the integument is still soft. This means that the growth of the organisms can be safely estimated by measuring moults, especially if that measure is made on the first segment of the second antennae - exopodite -, so long as the moult is not always obtained intact. Following this observation, the analysis of the allometric relationship between the exopodite length (EL) and the total body length (BL) is useful for subsequent estimations of growth parameters.

Therefore, the main goal of this work concerns the regression analysis of the two allometric measurements above mentioned, a support step that can be applied in ecotoxicological studies.

Thus, four species of daphnids were used: Daphnia magna Straus and Ceriodaphnia dubia Richard, two standardized species currently utilized in ecotoxicological experiments; Daphnia longispina O.F. Müller and Ceriodaphnia pulchella Sars, two autochthonous species in Portuguese shallow lakes (Barros 1994, Abrantes 2001, Abrantes 2003). 


\section{Methods}

\section{Organisms and laboratory cultures}

Four cladocerans species were used for measurements: Daphnia magna, from the single clone A (sensu Baird et al. 1989 a); Daphnia longispina, from a single clone developed from a population sample captured in Vela lake (Quiaios, Portugal) and cultured in laboratory since the beginning of 2001 (Antunes et al. 2003); Ceriodaphnia dubia, from a single clone provided by «Aqua Survey Inc.»; Ceriodaphnia pulchella, from a population sample also obtained in Vela lake. According to Abrantes (2001), this last species was not able to withstand to lab culture conditions; thus, $C$. pulchella field collected individuals were directly measured without being reared in lab.

Clones of D. magna, D. longispina and C. dubia were maintained in $800 \mathrm{ml}$ glass beakers with ASTM hard water (ASTM 1980), supplied with an organic additive (Baird et al. 1989 b) and fed with Pseudokirch-

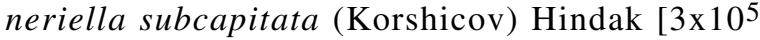
cells.ml-1 for D. magna (OECD 1996), $1.5 \times 10^{5}$ cells.ml-1 for D. longispina (Antunes 2003) and for $C$. dubia]. In any case, it was established that feeding and removal of the culture medium elapsed three times per week. The photoperiod was kept at $16^{\mathrm{L}}: 8^{\mathrm{D}}$ and the temperature of the cultures was maintained on $20 \pm 1^{\circ} \mathrm{C}$.

\section{Measurement procedures}

To evaluate the relation between the EL and BL for each species, it was used a stereomicroscope with magnifications of 32x, 57x (for Daphnia sp. and for $C$. dubia) and $114 \mathrm{x}$ for measurements of $C$. pulchella. The precision of the measurements was $15 \mu \mathrm{m}$ for $32 \mathrm{x}$, $8.5 \mu \mathrm{m}$ for $57 \mathrm{x}$ and $4.25 \mu \mathrm{m}$ for $114 \mathrm{x}$. Considering BL as the distance from the top of the head until the base of the carapace spine, and EL as the distance, on the central axis, from the base to the top of the first exopodite of the second antennae, measures were made in a total of 349 animals, for $D$. magna, 210 animals, for $D$. longispina, 281 animals, for C. dubia, and 293 animals, for $C$. pulchella. This last species presents, characteristically, a much reduced carapace spine (Amoros 1984), what reduces the probabilities of damage its structure while handling the organisms. In fact, for this species, it was observed that measures of BL that included the end of carapace spine were more coherent than those that did not include it. Therefore, to the same class of BL, weighty differences were found for BL considered as the distance between the top of the head till the end of carapace spine or as the distance from the top of the head till the base of the spine. Thereby, for $C$. pulchella BL was measured as the distance between the top of the head till the end of the carapace spine.

Generally, measures were taken from the day zero up to the day 21 , always trying to reach all the growing points of the animals. Notwithstanding, this specification was not followed for C. pulchella, once the age of the measured individuals could not be known. In this way, an effort was done in order to cover a wide range of body lengths, trying to reach the best fit of BL versus EL regression.

\section{Results and discussion}

As mentioned above, the obtained values were plotted following a linear regression principle (Figure 1) (Sokal \& Rohlf 1987). The confidence limits calculated for each slope are presented in Table I.

By direct observation of figure 1, it can be immediately pointed out some similarity on the distribution of the data on the plot area: the regression points appear as series of consecutive parallel lines which reflects the crustaceans (daphnids, in this case) characteristic discontinuous growth. Additionally, it is possible to observe that the increment in body size is accompanied by the increment in exopodite size.

\begin{tabular}{lcccc}
\hline \multicolumn{5}{c}{ Species } \\
\hline & D. magna & D. longispina & C. dubia & C. pulchella \\
$\mathbf{b}$ & 10.499 & 10.641 & 8.829 & 8.450 \\
$\mathbf{C L}_{1}$ & 10.7804 & 10.9547 & 9.0830 & 8.7572 \\
$\mathbf{C L}_{2}$ & 10.2176 & 10.3273 & 8.5750 & 8.1428 \\
\hline
\end{tabular}




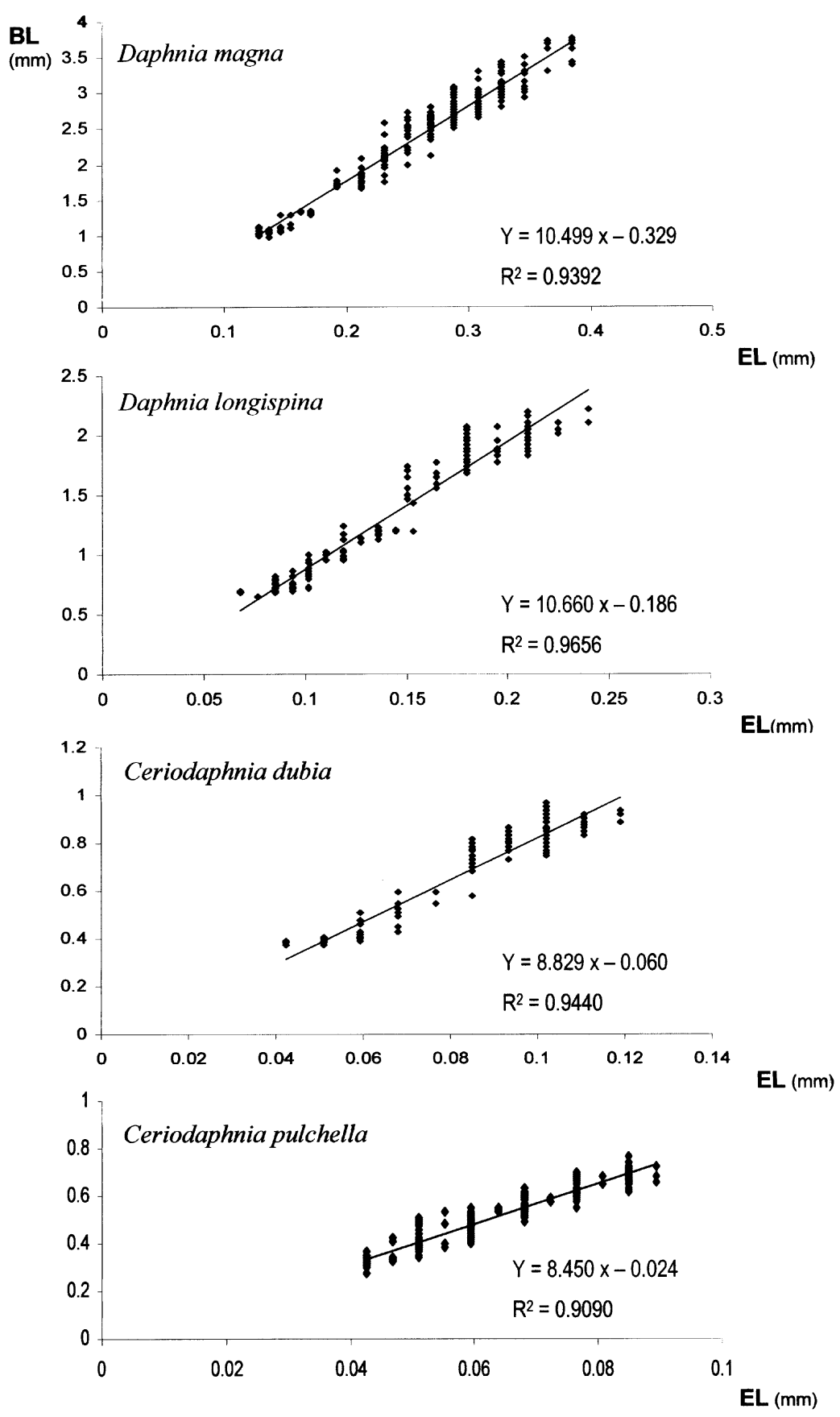

Fig. 1. Allometric relations between body (BL) and exopodite (EL) lengths for D. magna, D. longispina, C. dubia and C. pulchella. R-square values $\left(\mathrm{R}^{2}\right)$ and equations for each regression analysis are presented. 
Actually it is noticeable that there is similarity between slopes determined for organisms of the same genus (10.499 and 10.660 for D. magna and D. longispi$n a$, respectively; 8.829 and 8.450 for $C$. dubia and $C$. pulchella, respectively). Additionally, it is observable that for the smaller species (Ceriodaphnia sp.) the regressions present lower slopes, which means that the growth of the exopodite is proportionally greater than for the larger species.

In general, it was possible to find high R-square values $(>0.900)$ for the regressions, which confirmed that the measure of exopodite is a good estimator of body length. Notwithstanding, the R-square of $C$. pulchella was the lowest. Actually, the number of measured organisms was not much lower than that considered for the other species. Therefore, the reduced R-square for C. pulchella may be addressed to the smaller size of individuals, which can constrain the measurement accuracy (Bottrell et al. 1976). Moreover, once this species was directly measured from a sampled field population, it is also possible the occurrence of different clonal lines, which may reduce the data fit.

Although any information was obtained for $C . d u$ bia, similar slopes were found in other allometric studies for different clones of Daphnia magna [10.90, 10.61, 11.47, 11.42, 10.70, 10.65 (Soares 1989)], Daphnia longispina [10.33, 10.21, 10.28 (Barros 1994); 10.50 (Silva 1999)] and Ceriodaphnia pulchella [7.09, 7.42, 7.45 (Barros 1994)]. In spite of this, three slopes of D. magna, two of D. longispina and none of $C$. pulchella were included in our correspondent confidence limits. Actually, except for Silva (1999), the sizes of samples were below those considered by us, what may reduce the accuracy of the respective slopes. Moreover, these differences may be related to clonal variability associated to the studied allometric measures. However, if some of the slopes are included in the confidence limits of our regression analysis, the relevance of the differences that can be introduced by factors like clonal variability, may not interfere for great differences in the equations and consequently in the R-square values.

\section{References}

Abrantes N. 2001. - Dinâmica populacional de Ceriodaphnia pulchella (Crustacea, Cladocera). Ms. C. Thesis, Departamento de Biologia da Universidade de Aveiro, Aveiro, Portugal 81 p.
Abrantes N. \& Gonçalves F. 2003. - The dynamics of Ceriodaphnia pulchella (Cladocera) in laboratory. Acta Oecol., 24: S245-S249.

ASTM 1980. - Standard Practice for Conducting Acute Toxicity Tests with Fishes, Macroinvertebrates and Amphibians, Report E-760-80. ASTM, Philadelphia.

Amoros C. 1984. - Introduction pratique à la systématique des organismes des eaux continentales françaises. Bull. Soc. Linn. Lyon, 3: $72-144$.

Antunes S.C., Castro B.B. \& Gonçalves F. 2003. - Chronic responses of different clones of Daphnia longispina (field and ephippia) to different food levels. Acta Oecol., 24: S325-S332 Suppl.

Baird D.J., Barber I., Bradley M., Calow P. \& Soares A.M.V.M. 1989 a. - The Daphnia bioassay: a critique. Hydrobiologia, 188/18: 403-406.

Baird D.J., Soares A.M.V.M., Girling A., Barber I., Bradley M. \& Calow P. 1989 b. - The long maintenance of Daphnia magna Straus for use in ecotoxicity tests: problems and prospects. Pages 144-148 in Proceedings, $1^{\text {st }}$ European Conference on Ecotoxicology. Lokke H., Tyle H. \& Bro-rasmussen (eds). Copenhagen, Denmark.

Barata C., Baird D.J., Amat F. \& Soares A.M.V.M. 2000. - Comparing population responses to contaminants between labotatory and field: an approach using Daphnia magna ephippial egg banks. Funct. Ecol., 14: 513-523.

Barros P. 1994. - Implicações ecotoxicológicas de cianobactérias em cladóceros. Ms. C. Thesis, Faculdade de Ciências e Tecnologia da Universidade de Coimbra, Coimbra, Portugal, $84 \mathrm{p}$.

Baudo R. 1987. — Ecotoxicological testing with Daphnia. Pages 461-481 in Daphnia. Peters R.H. \& De Bernardi R. (eds.). Memorie dell' Istituto Italiano di Idrobiologia 45, Verbania.

Bottrell H.H., Duncan A., Gliwicz Z.M., Grygierek E., Herzig A., Hillbricht-Ilkowska A., Kurasawa H., Larsson P. \& Weglenska T. 1976. - A review of some problems in zooplankton production studies. Pages 420-456 in A manual on methods for the assessment of secondary productivity in fresh waters. Downing J.A. \& Rigler F.H. (eds.). Blackwell Scientific Publications, Québec, Canada.

Forbes V.E. \& Calow P. 1999. - Is the per capita rate of increase a good measure of population-level effects in ecotoxicology? Environ. Toxicol. Chem., 18: 1544-1556.

OECD 1996. - Daphnia magna reproduction test. Guidelines for Testing of Chemicals, $n^{\circ} 202$, Part II. Organization for Economic Cooperation and Development, Paris, France, 25 p.

Silva P.C.L.D. 1999. — Lagoa das Braças: um caso de estudo do processo de eutrofização. Ms. C. Thesis, Faculdade de Ciências e Tecnologia da Universidade de Coimbra, Coimbra, Portugal, $83 \mathrm{p}$.

Soares A.M.V. M. 1989. - Clonal variation in Life-History traits in Daphnia magna Straus (Crustacea, Cladocera) - Implications for ecotoxicology. Thesis submitted for the degree of PhD in the Department of Animal and Plant Sciences, University of Sheffield, Sheffield, UK, 162 p.

Sokal R.R. and Rohlf F.J. 1987. — Introduction to biostatistics - $2^{\text {nd }}$ edition. W. H. Freeman and Company, New York, 363 p. 